\title{
Kruh v egyptské matematice
}

\author{
doc. RNDr. Jindřich Bečvář, CSc. \\ Ústav aplikované matematiky, Fakulta dopravní, \\ České vysoké učení technické v Praze \\ $\triangle$ becvajin@fd.cvut.cz
}

\author{
Orientalia Antiqua Nova XXI \\ ISBN 978-80-261-1039-2 \\ Západočeská univerzita v PIzni, 2021 \\ https://doi.org/10.24132/ZCU.2021.10392-1-14
}




\section{Abstract}

The article analyzes five exercises (R50, R48, R41, R42 and R43) from the Rhind Mathematical Papyrus (deposited in the British Museum) that comes from the Second Intermediate Period of Egypt and is one of the best known examples of ancient Egyptian mathematics. One exercise (K2) from the Kahun Mathematical Papyrus (British Museum) is also discussed. The exercise R50 shows how Egyptian scribes calculated the area of a circle with a given diameter. The exercise R48 compares the area of a circle with a given diameter to that of its circumscribing square. Four other exercises demonstrate how to calculate the volume of a cylindrical grain silo with a given diameter and height. The author explains the algorithm which was used by Egyptian calculators. $\mathrm{He}$ also offers three ways how they could find a fairly accurate calculation, and how they approximated the value for $\pi$ and compared Egyptian approximation with the approximation using by Babylonian scribes as well as Greek mathematicians. 


\section{Úvod}

Historii starověkého Egypta členíme do následujících období.

Archaická doba (3200-2700)

Archaická doba odstartovala sjednocení Egypta a založení velké řiše. Zrodilo se písmo a začalo se intenzivně rozvijet.

Stará ríǐe (2700-2180)

Stará ríše znamenala první velký rozmach Egypta. Byly budovány chrámy, pohřebiště, postaveny velké pyramidy, sepsány tzv. texty pyramid, rozvijelo se hieroglyfické a hieratické písmo, vznikl kalendáŕ, narůstala vzdělanost.

\section{První přechodná doba (2180-1994)}

První přechodná doba byla obdobím rozpadu egyptské ríše.

\section{Střední říše (1994-1797)}

Střední řiše začala opětovným sjednocením země, představuje tzv. klasické období starého Egypta. Budovány byly zavlažovací kanály, chrámy, probíhaly administrativní reformy, rozvíjelo se písemnictví, byly sepsány matematické texty, jejichž znění se dochovalo do dnešních dnů.

\section{Druhá přechodná doba (1797-1543)}

Druhá přechodná doba byla poznamenána nadvládou Hyksósů. Z tohoto období zůstaly zachovány opisy starších matematických textů.

Nová říše (1543-1078)

Nová říše nastolila nový rozvoj starověkého Egypta. V Údolí králů byly budovány hroby, byly postaveny chrámy v Karnaku a Luxoru, byla sepsána Kniha mrtvých. 
Třetí přechodná doba (1078-715)

Třetí přechodná doba byla časem opětovného rozpadu říše, sever byl ovládán Libyjci.

\section{Pozdní doba (715-332)}

Pozdni doba přinesla jen krátký rozvoj, následovala okupace Egypta Asyrskou a Perskou říší. Roku 332 př. Kr. byl Egypt na tři století ovládnut Řeky a později Římany.

\section{Matematické texty}

Egyptských matematických textů z předřeckého období se dochovalo neskutečně málo. Nejvýznamnější jsou papyry Rhindův a Moskevský.

Rhindův papyrus (též Ahmosův, resp. Londýnský) je uchováván v Britském muzeu v Londýně (British Museum). Roku 1858 jej v Luxoru zakoupil Alexander Henry Rhind (1833-1863), skotský znalec starožitností. Kolem roku 1560 př. Kr. jej přepsal z materiálu pocházejícího z 19. století př. Kr. písař Ahmose. Slepen byl ze čtrnácti papyrových listů, dochoval se ve dvou částech o rozměrech $319 \times 33 \mathrm{~cm}$ a $206 \times 33 \mathrm{~cm}$. Jedná se o částečně tematicky členěnou sbírku úloh, které značíme $\mathbf{R} 1$ až $\mathbf{R 8 7}$, s návody a řešeními.

Moskevský papyrus (též Goleniščevův) je uložen v Puškinově muzeu krásných umění v Moskvě. Roku 1893 jej získal ruský egyptolog Vladimír Semjonovič Goleniščev (1856-1947). Napsán byl v Druhé přechodné době, jedná se o opis staršiho textu ze Střední říše. Slepen byl z jedenácti listů, je poměrně úzký, jeho rozměry jsou $544 \times 8 \mathrm{~cm}$. Není tematicky uspořádán, snad představoval jakýsi test znalostí. Úlohy $v$ něm obsažené značíme M1 až M25. 
Méně významnými matematickými texty jsou Káhúnské papyry (Britské muzeum), Dřevěné tabulky (Egyptské muzeum v Káhiře), Berlínský papyrus (Egyptská sbírka Pruské akademie v Berlíně) a Kožený svitek (Britské muzeum). Pocházejí ze Střední řiše, resp. z Druhé přechodné doby. Nejsou tak významné jako Rhindův či Moskevský papyrus.

Je třeba důrazně upozornit na to, že výše uvedené matematické texty byly určeny $\mathrm{k}$ výuce písařu a počtár̆u (nevíme však, jak pokročilých). Nelze proto z nich dělat seriózní závěry o úrovni matematiky ve starém Egyptě. Ze všech projevů egyptské civilizace však usuzujeme na mimořádně vysokou úroveň matematických znalostí a dovedností již $v$ době před pěti tisíciletími. Stačí uvážit geometrické a počtářské schopnosti zcela nezbytné k projektování a organizaci obrovských staveb, které vznikaly již ve Staré ríši.

\section{Aritmetika}

Staří Egyptané počitali v desítkové nepoziční soustavě, jednotky, desítky, stovky atd. byly značeny různými symboly. Sčitání a odčíání prováděli poměrně jednoduše - přidáváním, resp. odebíráním znaků príslušných čísel. Násobili pomocí postupného zdvojnásobování násobence a následného sčítání. Dělili obdobným způsobem - postupně zdvojnásobovali dělitele, dokud z jeho násobků nesložili dělence. Zápis dělení se proto neodlišuje od zápisu násobení, rozlišíme je však podle kontextu.

Egyptané pracovali pouze s tzv. kmennými zlomky, tj. se zlomky, které maji v čitateli jedničku, a se zlomkem $2 / 3$. Vzhledem $\mathrm{k}$ tomu, že při násobení a při dělení čísla zdvojnásobovali, museli vědět, jak „zdvojnásobit“ kmenný zlomek, tj. (v našem smyslu) jak vyjádřit zlomek s dvojkou v čitateli součtem kmenných zlomků. Je-li 
sudý jmenovatel, není to problém, zlomek Ize ( $v$ našem smyslu) krátit. Problém je, když je jmenovatel liché číslo. Rhindův papyrus obsahuje tzv. "tabulku 2 lomeno n“, která uvádí rozklady zlomků s dvojkou v čitateli a lichým jmenovatelem na součet kmenných zlomků, a to pro $n=5, \ldots, 101$. Část takovéto tabulky (pro $n=5, \ldots, 21$ ) je rovněž na jednom z Káhúnských papyrů.

\section{Geometrie}

Egyptské matematické texty obsahuji úlohy věnované výpočtu obsahů rovinných útvarů (čtyrúhelník, obdélník, trojúhelník, lichoběžník, kruh), objemů těles (krychle, kvádr, hranol, jehlan, komolý jehlan, válec) a sklonů rovin (sklony stěn pyramid). Znovu zdůrazněme, že již před pěti tisíci lety musely být ve starém Egyptě na značné úrovni praktické geometrické dovednosti (vyměřování polí, projektování staveb, tj. vytyčování půdorysů, orientace vůči světovým stranám atd.).

\section{Obsah kruhu}

Zajímavou částí egyptských matematických textů jsou partie související s výpočtem obsahu kruhu. Jedná se o úlohy R50, R48, R41, R42, R43 Rhindova papyru a o úlohu K2 jednoho z Káhúnských papyrů. Příklad R50 podává návod na výpočet obsahu kruhu o průměru 9 chet. Od hodnoty průměru se odečte jedna devítina, vychází 8 , toto číslo se umocní. Obsah kruhu o průměru 9 chet je tedy 64 chet $^{2}=64$ secat. Zajímavé je, že jednotka chet je poměrně veliká; chet je 100 loktů, přičemž loket je přibližně $52 \mathrm{~cm}$. Jednalo se tedy o kruh o průměru zhruba 468 metrů. V příkladu R50 tedy provedli „kvadraturu kruhu“ - obsah kruhu o průměru 9 chet nahradili obsahem čtverce o straně 8 chet. Př́ḱlad R50 vypadá (v překladu) zhruba takto: 
R50. Metoda výpočtu [obsahu] kruhové plochy o průměru 9 chet.

Jaký je obsah její plochy?

Odečti $\frac{1}{9} \mathrm{z}$ toho, je to 1 , zbytek je 8 .

Počítej s 8 8-krát, vyjde 64 .

Toto je její obsah v ploše: 64 secat.

$$
\begin{aligned}
& 19 \\
& \frac{1}{9} \quad 1
\end{aligned}
$$

Odečíst od toho, zbytek 8.

$\begin{array}{llrl}1 & 8 & 4 & 32 \\ 2 & 16 & \backslash 8 & 64\end{array}$

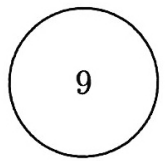

Obsah plochy

64 secat

Egyptská kvadratura kruhu je tedy takováto: čtverec, který má „stejný“ obsah jako kruh o průměru $d$, resp. poloměru $r$, má stranu $8 / 9 \cdot d$, resp. ${ }^{16} / 9 \cdot r$. Obsah kruhu byl tedy ve starém Egyptě vyjádřen hodnotou ${ }^{64} / 81 \cdot d^{2}$, resp. ${ }^{256} / 81 \cdot r^{2}$. Vydělením dostaneme přibližně $3,16 \cdot r^{2}$. "Egyptské $\pi$ “ je tedy 3,16.

Na Rhindově papyru předchází příkladu R50 příklad R48. Neobsahuje žádný text, jeho smyslem je patrně srovnání obsahů kruhu (64) a opsaného čtverce (81). Porovnejme zápis př́kladu R48 na Rhindově papyru a jeho přepis (egyptský zápis se čte zprava doleva). Obrázek je převzat z Bečvář, Bečvářová a Vymazalová 2003, 85. 


\begin{tabular}{rrrr}
\multicolumn{1}{r|}{ R48. } & \\
1 & 8 & $\backslash 1$ & 9 \\
2 & 16 & 2 & 18 \\
4 & 32 & 4 & 36 \\
$\backslash 8$ & 64 & $\backslash 8$ & 72 \\
& & celkem & 81
\end{tabular}

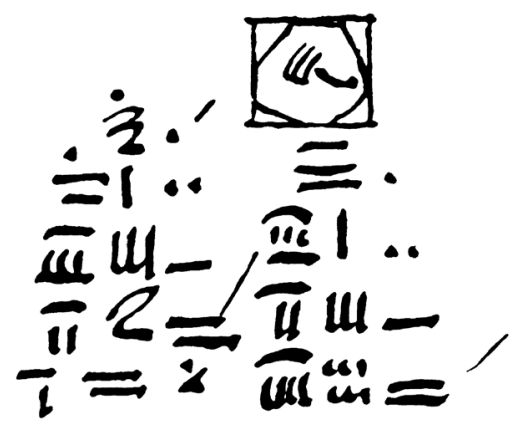

Velkým problémem pro historiky matematiky je otázka, jak ve starém Egyptě dospěli k výše uvedenému algoritmu pro výpočet obsahu kruhu. Naznačíme tři možnosti, jak k tomu mohlo dojít. Všechno jsou ovšem jen spekulace.

Představme si, že kruh o průměru $d$ je vepsán do čtverce, který je rozdělen na devět stejných čtverců (viz obrázek). Aproximujme obsah kruhu obsahem osmiúhelníku, který získáme tak, že od čtyř rohových čtverců odkrojíme úhlopřičkou jejich poloviny. Obsah získaného osmiúhelníku je tedy roven obsahu sedmi menších čtverců, tj. sedmi devítinám obsahu velkého čtverce, tj. $7 / 9 \cdot d^{2}=63 / 81 \cdot d^{2}$. Egyptský způsob však udává hodnotu ${ }^{64} /{ }_{81} \cdot d^{2}$, která je přesnějši (viz hodnoty na obrázku). Snad staři Egyptané zvětšili čitatel 63 o jedničku, aby bylo možno číslo 64 odmocnit. Tak mohli dojít k vyjádření obsahu ( $v$ našem smyslu) výrazem $(8 / 9 \cdot d)^{2}$. 




$S=\pi r^{2}=\frac{1}{4} \pi d^{2}$,

kde $\frac{1}{4} \pi \doteq 0,7854$

$$
S \doteq \frac{7}{9} d^{2}=\frac{63}{81} d^{2}
$$$$
S \doteq\left(d-\frac{1}{9} d\right)^{2}=\frac{64}{81} d^{2} \doteq 3,16 r^{2}
$$

$\frac{63}{81}=\frac{7}{9} \doteq 0,7777 \quad+0,0077$

$\frac{64}{81} \doteq 0,7901$

$-0,0047$

Druhá úvaha je představena na dalším obrázku. Kruh o průměru $d$ je zakreslen ve čtvercové síti, přičemž prochází osmi mřižovými body. Pomocí Pythagorovy věty snadno vyjádříme délku strany a čtverce pomocí průměru $d$, resp. poloměru $r$ (viz obrázek). Pokud obsah kruhu o poloměru $r$ aproximujeme obsahem čtverce se stranou $a$, bude obsah kruhu vyjádřen hodnotou $a^{2}=$ $3,2 \cdot r^{2}$. To však neodpovídá egyptskému výpočtu. Vrátíme se proto k vyjádření hodnoty $a$, kde ve jmenovateli je odmocnina z 80. Zvětšíme-li tuto hodnotu o jedničku, bude možno číslo 81 v oboru přirozených čísel odmocnit. Hodnota a se tím mírně zmenší a bude přesně odpovídat egyptské kvadratuře kruhu. 


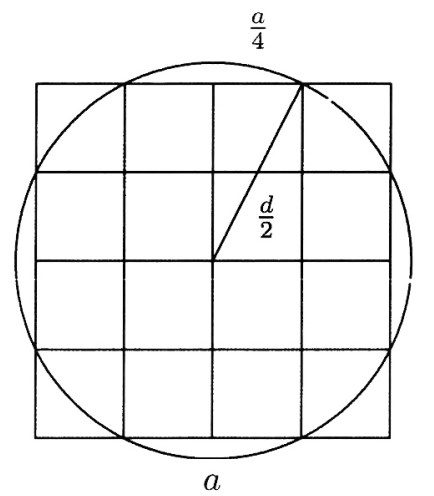

$$
\begin{aligned}
& \left(\frac{a}{2}\right)^{2}+\left(\frac{a}{4}\right)^{2}=\left(\frac{d}{2}\right)^{2} \\
& a=\frac{2}{\sqrt{5}} d=\frac{8}{\sqrt{80}} d \\
& a^{2}=\frac{4}{5} d^{2}=3,2 r^{2} \\
& a \doteq \frac{8}{\sqrt{81}} d=\frac{8}{9} d
\end{aligned}
$$

Tretí úvaha je na dalším obrázku, kde je kruh vepsán do čtverce sestávajícího z $18 \times 18=324$ malých čtverečků. V každém rohu velkého čtverce odebereme 17 malých čtverečků a obsah kruhu aproximujeme zbylou bílou plochou. $Z$ velkého čtverce jsme tedy odebrali $4 \times 17=68$ malých čtverečků, zbylo $324-68=256=$ $16 \times 16$ čtverečků. $\mathrm{K}$ bílé ploše nyní přidáme $4 \times 8$ čtverečků v rozích a odebereme $4 \times 8$ čtverečků po stranách. Tím jsme bílou plochu přetvořili na čtverec $16 \times 16$ a dospěli k egyptské kvadratuře kruhu: od průměru 18 jsme odebrali jednu devítinu, 18 - 2 = 16, a obsah kruhu aproximovali obsahem čtverce o straně 16.

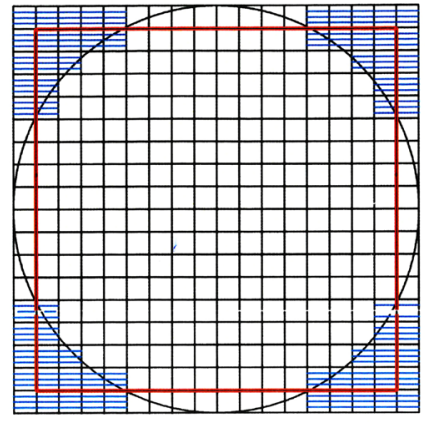

Velký čtverec je složen

z $18^{2}=324$ malých čtverečků.

$\mathrm{V}$ každém rohu $\mathrm{z}$ něj odebereme

17 čtverečků, tj. celkem 68 čtverečků.

Aproximujeme obsah kruhu bílou plochou $324-68=256=16^{2}$ čtverečků.

Bílou plochu můžeme pretvořit na čtverec.

Ze čtverce $16^{2}$ odebráno $4 \cdot 8=32$ čtverečků a přidáno $4 \cdot 8=32$ čtverečků.

Zř̀jmě je $16=\frac{8}{9} \cdot 18$. 


\section{Objem válce}

$\mathrm{Na}$ Rhindově papyru jsou tři úlohy, v nichž je třeba vypočítat objem válcové sýpky. $V$ přikladu $\mathbf{R} 41$ je úkolem vypočitat objem takové sýpky o průměru základny 9 a výšce 10 . Výpočet probíhá víceméně jako $v$ dnešních školách, obsah podstavy se vynásobí výškou. Využije se přitom již známý postup výpočtu obsahu kruhu. Př́klad je mírně komplikován převodem jednotek. Zadané rozměry sýpky jsou v loktech, jeji objem je tedy vypočten v krychlových loktech. Vypočtená hodnota je pak zvětšena o polovinu, nebot jeden krychlový loket zrna odpovídá půl druhému pytli zrna. Počet pytlů je dále vydělen dvaceti, výsledek je přepočten na podstatně větší jednotky (tzv. stovky čtyřnásobných měřic). Můžeme si představit, že dvacet pytlů je naloženo na vozík. Viz následující obrázek.

R41. Metoda výpočtu kruhové sýpky (o rozměrech) 9, 10.

Odečti $\frac{1}{9}$ z 9 . Je to 1 , zbytek 8 . Počítej s 8 8-krát, vyjde 64 .

Počítej se 64 10-krát, vyjde 640 .

Přidej k tomu $\frac{1}{2} \mathrm{z}$ toho, vyjde 960 . To je jeho objem v pytlích.

Vypočti $\frac{1}{20}$ z 960 . Je to 48 .

To je to, co do ní vejde ve stovkách čtyřnásobných měřic:

48 stovek čtyřnásobných měřic obilí.

Tvar řešení tohoto:

$\begin{array}{rrrrrr}1 & 8 & \backslash 8 & 64 & \text { celkem } & 960 \\ 2 & 16 & 1 & 64 & \frac{1}{10} & 96 \\ 4 & 32 & \backslash 10 & 640 & \frac{1}{20} & 48 \\ & & \backslash \frac{1}{2} & 320 & & \end{array}$


Obdobným přikladem, který je však numericky náročnější, je príklad R42. Průměr základny je $10, z$ toho jedna devítina je $11 / 9$ a zbytek je $8 \% / 9$. Zlomek $8 / 9$ je ovšem nutno vyjádřit pomocí kmenných zlomků, což výpočet komplikuje. Viz obrázek.

R42. Kruhová sýpka (o rozměrech) 10, 10.

Odečti $\frac{1}{9}$ z 10 , je to $1 \frac{1}{9}$, zbytek je $8 \frac{2}{3} \frac{1}{6} \frac{1}{18} \ldots$ atd.

Výsledky: $\quad 790 \frac{1}{18} \frac{1}{27} \frac{1}{54}, \quad 1185, \quad 59 \frac{1}{4}$.

V následujícím příkladu $\mathbf{R 4 3}$ je třeba vypočitat objem válcové obilnice o průměru 9 a výšce 6 . Př́klad je však zapsán chybně, chybami je poznamenán i výpočet. Jeden z Káhúnských papyrů obsahuje př́klad K2, který snad Ize chápat jako výpočet objemu válcové obilnice o průměru 12 a výšce 6 . Není bohužel doprovázen žádným textem, připojený obrázek však takovouto interpretaci podporuje.

\section{Závěr}

Pro výpočet obvodu o a obsahu $S$ kruhu dnes užíváme konstantu $\pi$. Ve škole jsme se naučili vzorce

$0=2 \pi r$,

$S=\pi r^{2}$,

kde $\pi=3,141592653589793238462643383 \ldots$,

pro běžné účely stačí brát za $\pi$ hodnotu 3,14. Dnes víme, že číslo $\pi$ je iracionální, tj. nelze je vyjádřit zlomkem $s$ celočíselným 
čitatelem a jmenovatelem. Ve druhé polovině 19. století bylo dokázáno, že je $\pi$ dokonce číslo transcendentní, tj. není kořenem žádné algebraické rovnice s celočíselnými koeficienty. Tímto výsledkem byl s konečnou platností negativně vyřešen problém kvadratury kruhu, který byl vysloven ve starém Řecku již někdy $\checkmark$ 5. století př. Kr.: pravítkem a kružítkem nelze sestrojit stranu čtverce, který má stejný obsah jako daný kruh.

Ve starém Egyptě byla v polovině 2. tisíciletí př. Kr. pro výpočet obsahu kruhu místo našeho $\pi$ užívána hodnota 3,16, zatímco v Mezopotámii ve stejné době (i daleko později) méně přesná hodnota 3. Zhruba o patnáct století později vypočetl řecký matematik a fyzik Archimédés (asi 287 až 212) velmi nápaditým postupem horní a dolní odhad obvodu kruhu, a nalezl tak ( $v$ moderní interpretaci vyjádřeno) horní a dolní odhad čísla $\pi$. Převedeme-li Archimédovy zlomky na desetinná čísla, dospějeme k vymezení

$3,140909<\pi<3,142826$,

které je přesné na dvě desetinná místa. Od Archiméda pochází i jednodušši odhad

$3^{10} / 71<\pi<31 / 7=22 / 7$.

Archimédovu přibližnou hodnotu ${ }^{22} / 7$ pro číslo $\pi$ jsme uživali ve škole.

O matematice ve starém Egyptě viz Bečvářr, Bečvářová a Vymazalová 2003 a Vymazalová 2006, o Rhindově papyru viz Robins a Shute 1990, o geometrii viz Neugebauer 1931, o obsahu kruhu viz Engels 1977 a Gerdes 1985. 


\section{Literatura}

Bečvár̆, Jindřich, Martina Bečvářová a Hana Vymazalová. 2003. Matematika ve starověku. Egypt a Mezopotámie. Edice Dějiny matematiky, svazek č. 23. Praha: Prometheus.

Engels, Hermann. 1977. "Quadrature of the Circle in Ancient Egypt.“ Historia Mathematica 4: 137-140.

Gerdes, Paulus. 1985. „Three Alternate Methods of Obtaining the Ancient Egyptian Formula for the Area of a Circle." Historia Mathematica 12: 261-268.

Neugebauer, Otto. 1931. „Die Geometrie der ägyptischen Texte.“ Quellen und Studien zur Geschichte der Mathematik, Astronomie und Physik, Abt. B, Band 1. Berlin: J. Springer, 413-451.

Robins, Gay a Charles Shute. 1990. The Rhind Mathematical Papyrus. An Ancient Egyptian Text. The Trustees of the British Museum, London: British Museum Press.

Vymazalová, Hana. 2006. Staroegyptská matematika. Hieratické matematické texty. Edice Dějiny matematiky, svazek č. 31. Praha: Český egyptologický ústav. 